\title{
The seroepidemiology of toxoplasmosis in the lower Fraser Valley of British Columbia
}

\author{
EILEEN M PROCTOR MSC PhD ${ }^{1,2}$, SATYENDRA N BANERJEE PhD ${ }^{1,3}$
}

\begin{abstract}
EM PRoctor, SN BANERJEE. The seroepidemiology of toxoplasmosis in the lower Fraser Valley of British Columbia. Can J Infect Dis 1994;5(5):218-223.

OвJестіv: To determine the seroprevalence of toxoplasmosis in vegetarian and nonvegetarian members of different ethnic communities in the lower Fraser Valley of British Columbia.

DEsign: Serum samples were collected from 2027 participants drawn from various ethnic groups and tested by ELISA for the presence of immunoglobulin (Ig) G and IgM antibodies to Toxoplasma gondii. Coded questionnaires requesting information relevant to the study were completed by each participant. The study population comprised 1334 females and 693 males; ages ranged from 17 to 102 years.

MaIN REsults: Four hundred and nineteen (20.7\%) individuals were IgG positive with titres ranging from 1:100 to $1: 3200$. IgM antibodies were detected in only four individuals. The seroprevalence rose with increase in age but there was no significant difference between males and females. A positive correlation was shown between ingestion of meat and between consumption of unpasteurized milk and antibodies to $T$ gondii. Eighty per cent of females between the ages of 17 and 40, of all ethnic origins, were seronegative. Seropositivity did not differ between cat owners and non-cat owners.

ConcLusions: Women of childbearing age are at risk of acquiring toxoplasmosis during pregnancy and of transmitting the infection transplacentally. Consumption of undercooked meat and unpasteurized milk may result in the acquisition of toxoplasmosis. Data suggest that acquisition of toxoplasmosis is more likely via environmental oocysts or cysts in food source animals than by direct contact with cats.
\end{abstract}

Key Words: ELISA, Indirect immunofluorescence, Seroepidemiology. Toxoplasmosis

\section{Séroépidémiologie de la łoxoplasmose dans la vallée du fleuve Fraser en Colombie-Britannique}

ОвлестіF : Déterminer la séroprévalence de la toxoplasmose chez des membres végétariens et non végétariens de différentes communautés ethniques de la vallée du Fraser en Colombie-Britannique.

Modèle : Des échantillons de sérum ont été recueillis auprès de 2027 participants provenant de divers groupes ethniques et ils ont été soumis à un test Elisa pour y déceler la présence d'anticorps anti-immunoglobuline IgG et anti-IgM à l'endroit de Toxoplasma gondii. Des questionnaires codés demandant des renseignements pertinents pour l'étude ont été remplis par chaque participant. La population étudiée comprenait 1334 femmes et 693 hommes âgés de 17 à 102 ans.

voir page suivante

Division of Medical Microbiology. Department of Pathology ${ }^{1}$. University of British Columbia: National Centre for Diagnostic Parasitology (Morphology) ${ }^{2}$ and Provincial Laboratory, British Columbia Centre for Disease Control ${ }^{3}$, Vancouver, British Columbia Correspondence and reprints: Dr EM Proctor, Provincial Laboratory, BC Centre for Disease Control, 828 West 10 th Avenue, Vancouver, British Columbia V5Z 1L8. Telephone (604) 660-6005. Fax (604) 660-0403

Received for publication October 14, 1992. Accepted February 24, 1994 
Principaux Résultats : Quatre cent dix-neuf (20,7\%) sujets étaient séropositifs à l'égard de l'IgG avec des titres variant de 1:100 à 1:3 200. Des anticorps anti-IgM ont été décelés chez quatre individus seulement. La séroprévalence s'élevait avec l'àge, mais on n’a observé aucune différence significative entre les hommes et les femmes. Une corrélation positive a été établie entre ingestion de viande et consommation de lait non pasteurisé et la présence d'anticorps anti-T gondii. Quatre-vingt pour-cent des femmes âgées de 17 à 40 ans, de toutes origines ethniques, étaient séronégatives. La séropositivité n’a pas différé, que les sujets soient ou non propriétaires de chats.

Conclusions : Les femmes en âge de procréer sont exposées à un risque de toxoplasmose durant la grossesse qui peut se transmettre au foetus. La consommation de viande insuffisamment cuite ou de lait non pasteurisé pourrait entraîner une toxoplasmose. Selon les données, l'acquisition de la toxoplasmose est plus susceptible de se produire par contamination d'origine environnementale provenant de sources alimentaires animales que par contact direct avec les chats.

$\mathrm{O}$ VER THE PAST 30 YEARS THERE HAS BEEN A STEADY growth in the literature of articles on toxoplasmosis, indicating an increasing awareness on the part of physicians and veterinarians. The causative organism, Toxoplasma gondii, is a protozoan parasite which was first discovered in a North African rodent in the early part of the century (1). T gondii is ubiquitous in nature, and over 300 species of mammals and 30 species of birds have been identified as intermediate hosts of this parasite (2).

Humans acquire the infection either by eating undercooked meat containing viable cysts or by accidental ingestion of oocysts shed by infected cats. The relative importance of these two routes of infection is not clear. Nevertheless, the majority of infections is subclinical and passes unnoticed. Infection may also be acquired congenitally, as a result of organ transplantation or through the ingestion of unpasteurized milk, in particular goat's milk $(3,4)$. Infection with $T$ gondii is common throughout the world and studies have shown that 25 to $60 \%$ of the adults in both Canada and the United States have been exposed to this organism at some time in their life (5-9).

The aim of this study was to determine the seroprevalence of toxoplasmosis in vegetarian and nonvegetarian members of different ethnic communities in British Columbia. Those individuals who are at highest risk of acquiring toxoplasmosis are identified, as well as some of the factors that may predispose to infection with this parasite. The serological findings are presented and analyzed with reference to the demographic data.

\section{PATIENTS AND METHODS}

Seven millilitres of blood were drawn from each of 2027 participants, all of whom signed a consent form and completed a coded questionnaire. The participants were drawn from members of the East Indian Sikh, Moslem and Hindu communities, the Native community, Chinese, Japanese and other Asian communities, and from Caucasians of various ethnic origins. Participants who did not speak or read English were assisted with the completion of the questionnaire by an interpreter.

Specimens from the various East Indian communities were obtained during visits to the respective tem- ples and mosques at the time of their Sunday worship. Participation by members of the Native community was solicited through the Down Town Vancouver East Hastings Community Centre and a health unit. Other participants were sought from among the staff members of various laboratories, hospitals and institutions, including homes for the elderly, in the lower Fraser Valley region of British Columbia.

The questionnaire requested information on age, sex, dietary preferences, type of meat consumed and to what degree the meat was cooked (rare, medium rare etc), consumption of unpasteurized milk, occupation, cat ownership and, in the case of females, whether the individual was pregnant at the time of completion of the questionnaire.

Serum was separated immediately, coded to correspond to the questionnaire and stored at $-20^{\circ} \mathrm{C}$. Specimens were tested for the presence of antibodies to $T$ gondii by the Toxonostika IgG and IgM (Organon Technika) ELISA.

Statistical analysis was performed using Student's $t$ test, $\chi^{2}$ test and analysis of variance.

\section{RESULTS}

The 2027 individuals of various ethnic origins who provided blood specimens and completed questionnaires ranged in age from 17 to 102 years, with a median age of 55 and a mean age of 39.8. Sixty-six per cent of the study population was female (mean age 38.6 years) and $34 \%$ was male (mean age 42.2 ), with no significant difference between male and female ( $\mathrm{P}>0.05)$.

Four hundred and nineteen of the 2027 (20.7\%) individuals tested by ELISA immunoglobulin (Ig) G had antibodies to $T$ gondii, with titres ranging from $1: 100$ to 1:3200 (Figure 1). Only four individuals were positive by ELISA IgM: three with titres of $1: 100$ and one with a titre of 1:400. There was no significant difference in seropositivity between males $(22.4 \%)$ and females (19.5\%) (P>0.05).

The Caucasian participants (1112) numbered more than half of the study population and 225 (20.2\%) were seropositive. Forty-five per cent (915) of all the participants were non-Caucasian and 194 (21.2\%) were seropositive. The East Indian participants comprised 677 of 


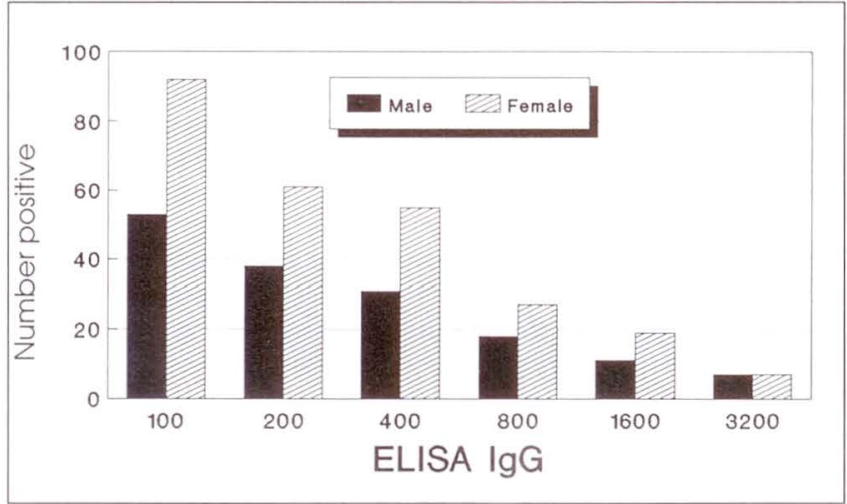

Figure 1) Toxoplasmosis reciprocal titres in the study popula tion; $n=419$ ( 158 males, 261 females)

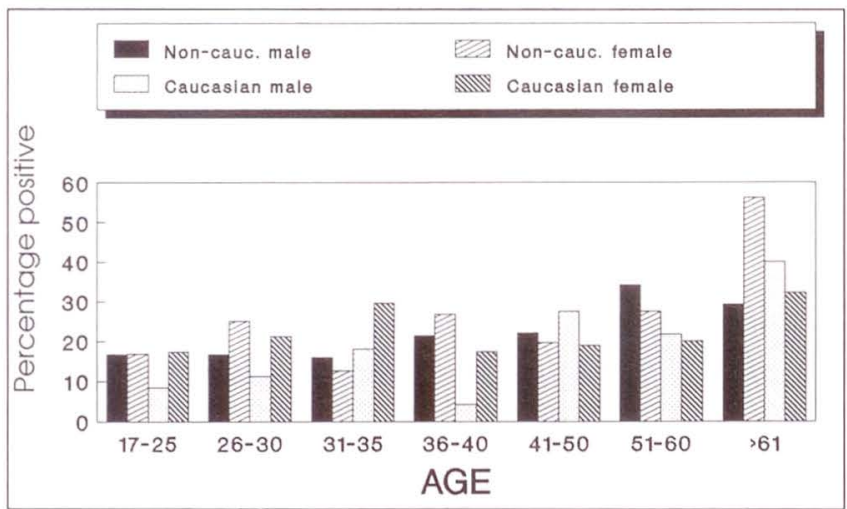

Figure 2) Toxoplasmosis age distribution by sex and ethnicity; n=2027 (non-Caucasian: 113 males, 81 females: Caucasian: 45 males, 180 females)

the study population and were from different religious groups: 311 Sikhs, 272 Hindus and 94 Moslems. One hundred and fifty-six (23\%) members of this group were positive by ELISA. Orientals formed the third-largest group of individuals and 27 of 174 (15.5\%) demonstrated antibodies to $T$ gondii. Included in this group were four Black participants, $75 \%$ of whom were ELISA IgG positive. Eleven of the 64 (17\%) Native participants had serological evidence of toxoplasmosis. Statistical analysis of the seropositivity differences among these groups indicated that there was a significant difference $(\mathrm{P}<0.05)$, and that the prime contributors to this difference were female Orientals $(\mathrm{P}<0.05)$ and female Natives $(\mathrm{P}<0.05)$.

Seroprevalence by age and sex: The overall positivity rose from $14.4 \%$ in the first age group, ie, 17 to 25 years, with an average of $19 \%$ and $16 \%$, respectively, for each five-year age increase to 35 . By age 40 the seropositivity was $20.5 \%$. For the next two decades the seropositivity rose to $20.9 \%$ and $27.3 \%$, respectively. The number of participants in each decade over age 61 was small and, therefore, they were all grouped together, with a seropositivity of $34 \%$. Figure 2 shows the percentage positivity by age group in both non-Caucasian and Caucasian participants. Overall, there was no signifi-

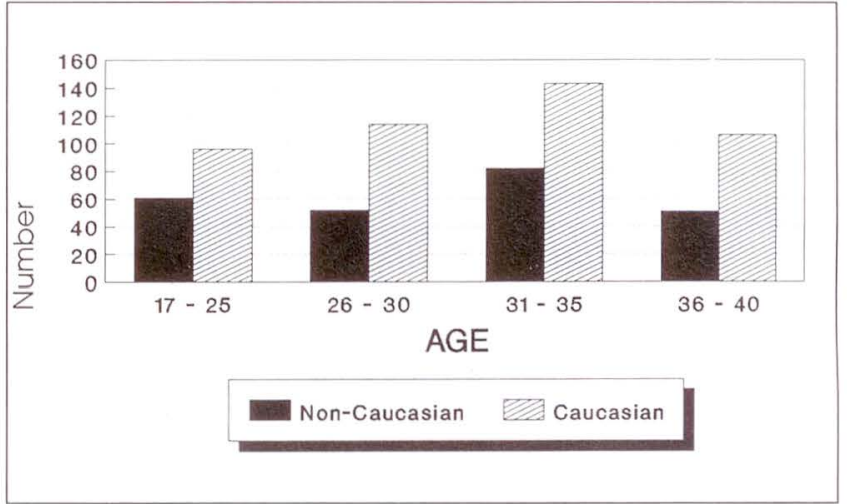

Figure 3) Toxoplasmosis female study participants of chilbear ing age who were ELISA-negative; $n=705$ (non-Caucasian: 246; Caucasian 459)

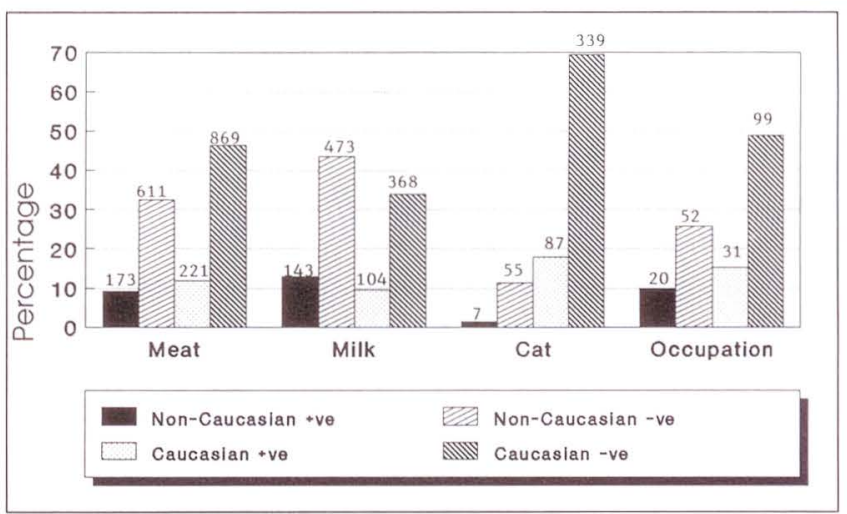

Figure 4) Toxoplasmosis risk factors versus ELISA immunoglobulin G results; $n=2027$

cant difference between male and female seropositvity in the different age groups ( $P>0.05)$.

Females comprised $66 \%$ (1338) of the study population. Of this number 261 (19.5\%) were ELISA IgG positive. Titres of 1:800 or greater were demonstrated in a fifth of those who were seropositive. However, none of the individuals with high levels of IgG antibodies were IgM positive.

Forty-nine of the female participants were pregnant, all except three were nonvegetarians and only 10 had serological evidence of exposure to toxoplasmosis. The seropositive females all consumed meat, seven owned a cat and four regularly drank unpasteurized milk. Twothirds of the pregnant females were seronegative and $75 \%$ of them consumed meat and owned a cat. Two of three who were vegetarians and five nonvegetarians also drank unpasteurized milk. Eighty-four per cent (246) and $82 \%$ (459), respectively, of non-Caucasian and Caucasian female participants within the childbearing years of 17 to 40 were seronegative (Figure 3).

Dietary preferences: Of $260(13 \%)$ vegetarian participants, $107(41 \%)$ had consumed meat at some stage of their life. The strict vegetarians, therefore, totalled 153. The majority of vegetarians were East Indians, with only 22 of 260 (8.5\%) being Caucasians. Forty-one non-Cau- 
casians and four Caucasian vegetarians were ELISA IgG positive.

Twenty-two per cent of non-Caucasians and $20 \%$ of Caucasians who had consumed meat, in one form or another, were seropositive (Figure 4). This was shown to be statistically significant $(\mathrm{P}<0.05)$. Table 1 shows the breakdown by ethnicity and antibody status in relation to the degree to which consumed meat was cooked.

Analysis of the different types of meat consumed found a seroprevalence among non-Caucasian participants ranging from $17.2 \%$ for pork consumption to $25.2 \%$ for those who consumed goat meat, with an average of $21.2 \%$ overall. By contrast the seroprevalence among Caucasians ranged from 18.5\% for poultry consumption to $19.8 \%$ for pork, with an average of $19.4 \%$ for six types of meat. Among Orientals, 24 of 159 (15\%) and 23 of 160 (14\%) who consumed mainly poultry and beef were seropositive. Of the 425 seronegative non-Caucasians, 234 (55\%) were East Indians who regularly consumed beef.

Risk factors - Cat ownership: Ninety-four of 488 (19.2\%) individuals who had owned a cat at some stage of their lives were ELISA IgG positive. This was not significantly different from the non-cat owners $(\mathrm{P}>0.05)$. Eighty-seven (93\%) of the seropositive individuals were Caucasian and 72 of this group were between 26 and 52 years of age. By contrast 55 (11.3\%) and 339 (69.5\%) non-Caucasian and Caucasian cat owners, respectively, were seronegative (Figure 4). Among Orientals, one of 21 cat owners and 21 of 141 non-cat owners were ELISA IgG positive.

Risk factors - Occupation associated with cats and meat handling: Of the 202 participants who indicated that their occupation fell into either of these two categories, 51 were seropositive (Figure 4). This was statistically significant $(\mathrm{P}<0.05)$. The serological findings of one individual - ELISA IgG greater than 1:3200, ELISA IgM 1:400 and immunofluorescent assay-IgG 1:2048 - were diagnostic of acute toxoplasmosis. This participant was a meat-cutter who had recently developed 'flu-like symptoms, at which time a lymph node was biopsied. He also owned a cat.

Risk factors - Consumption of unpasteurized milk: There was a significant difference in seropositivity between those who consumed unpasteurized milk and those who consumed pasteurized milk $(\mathrm{P}<0.05)$. Fiftyfour per cent of the participants, 472 Caucasians and 616 non-Caucasians, indicated that they had at some stage consumed unpasteurized milk (Figure 4). Twentytwo per cent and 23\%, respectively, of Caucasians and non-Caucasians within this group were seropositive. By contrast, of the 939 individuals who had never consumed unpasteurized milk, 116 (12\%) Caucasians and $51(5 \%)$ non-Caucasians were ELISA IgG positive. Seven of $30(23 \%)$ Orientals who had consumed unpasteurized milk were seropositive.
TABLE 1

Antibody status of ethnic groups by degree of cooking of meat consumed

\begin{tabular}{lcccc}
\hline & \multicolumn{2}{c}{ Caucasian } & \multicolumn{2}{c}{ Non-Caucasian } \\
& Positive (\%) & Negative (\%) & Positive (\%) & Negative (\%) \\
Number & 221 & 869 & $173^{*}$ & $611^{*}$ \\
Rare & $10(4.5)$ & $37(4.3)$ & $6(3.5)$ & $19(3.1)$ \\
$\begin{array}{l}\text { Medium } \\
\quad \text { rare }\end{array}$ & $58(26)$ & $226(26)$ & $12(7.0)$ & $46(7.5)$ \\
Medium & $79(36)$ & $347(40)$ & $25(14)$ & $130(21)$ \\
Well done & $74(33)$ & $259(30)$ & $130(75)$ & $416(68)$ \\
\hline *Included are 107 non-Caucasians with brief meat exposure
\end{tabular}

Statistical analysis: Risk of acquisition of toxoplasmosis in Caucasians born in Canada was found to be significantly different from that in Caucasians born outside of the country $(\mathrm{P}<0.00001)$, in Moslems $(\mathrm{P}<0.05)$ and in Orientals $(\mathrm{P}<0.02)$.

\section{DISCUSSION}

The age-specific seropositivity in the present study was considerably lower than that reported by other investigators, who have shown that the seroprevalence in populations studied in southern Ontario and Holland climbs to approximately $45 \%$ between the ages of 21 and 25 years and reaches a maximal value of 59\% in the age groups between 40 and $79(10,11)$. Although prevalence rates vary throughout the world and are influenced by geographic, climatic, ethnic and socioeconomic factors, in most populations tested there appears to be an increase with age, suggesting continued exposure throughout life (12-14). The seroprevalence recorded in the age groups above 50 years in the present study is not comparable to other findings because the number of participants was too small.

The study has shown that, in both the non-Caucasian and Caucasian communities, in the childbearing age group in this region of British Columbia, approximately four of five females are nonimmune and therefore at risk of acquiring toxoplasmosis during pregnancy and of transmitting the infection to the fetus. By contrast, one in four seropositive females over the age of 40 years, of all ethnic origins, had antibody levels of 1:800 or greater by ELISA, a level that is considered to be indicative of a more recent infection. However, IgM antibodies associated with acute infection were not demonstrated in any of the female participants with high levels of IgG.

Members of the different religious groups within the East Indian community were included in the study because of differences in the type of food consumed, particularly meat, as dictated by their religious beliefs. The Hindu and Moslem diets exclude beef and pork, respectively, whereas the diet of Sikhs and most Caucasians is indiscriminate. While the majority of vegetarians was East Indian, the $43 \%$ who had consumed 
meat had done so for only brief periods of time, usually during the early days of immigration to Canada. Although the consumption of raw or undercooked meat is regarded as one of the major routes of acquisition of toxoplasmosis, only $3 \%$ and $17 \%$, respectively, of the seropositive individuals consumed rare or medium rare meat. By comparison rare or medium rare meat was consumed by $22 \%$ of the ELISA-negative individuals. The percentage of seropositive Caucasians who consumed rare to medium rare meat was three times greater than non-Caucasian seropositives, a difference that is not too surprising given that the non-Caucasians comprised mainly East Indians who, in the preparation of their traditional dishes, cook their meat extremely well.

The consumption of lamb and pork has been shown to pose a greater risk of acquisition of toxoplasmosis than consumption of other types of meat (15-19), yet $76 \%$ and $80 \%$ of non-Caucasians and Caucasians, respectively, who consumed pork were seronegative. Similarly, the Orientals in the study indicated a preference for poultry, another possible source of infection (20); yet only 15\% were seropositive, suggesting that the method of cooking may prevent the acquisition of toxoplasmosis.

The difference of $19.2 \%$ and $20.8 \%$ in seroprevalence between cat owners and non-cat owners, respectively, was not statistically significant. This finding is in marked contrast to the findings in a Seattle, Washington study, in which the seroprevalence in cat owners was considerably greater than among those who denied ever having a cat as a pet (21).

In the present study cat ownership, either present or past, was much more prevalent among Caucasians than non-Caucasians and among females than males. Many members of the East Indian community expressed a distinct dislike of cats and preferred to have no contact with the animals.

Numerous studies and several family and community or group outbreaks have pointed to the major role played by cats in the transmission of toxoplasmosis, both through direct contact with humans and by contamination of the soil with oocysts (22-26). The seroprevalence in the present study of $28 \%$ and $24 \%$ in non-Caucasians and Caucasians, respectively, who had never owned or had direct contact with cats, points to oocysts in the environment and/or tissue cysts in consumed meat as the more likely source of infection in this group.

$T$ gondii-induced reproductive losses in goats have been reported from most countries around the world (27-31), and unpasteurized goat milk has been identified as the source of infection in at least two outbreaks $(3,4)$. While none of the participants acknowledged drinking raw goat's milk, more than 50\% of the individuals admitted to consumption of unpasteurized milk whenever the opportunity presented itself. The East Indian participants, who constituted 33\% of the study population, indicated that it was a regular practice to drink unpasteurized buffalo milk, both before their immigration to Canada and on return visits to India. Many of the Indo-Canadian participants commented on their preference for unpasteurized milk, irrespective of the source. While the sale of raw milk is illegal in British Columbia, it is evidently readily available and frequently purchased by members of the East Indian community.

Although little is known about toxoplasmosis in water buffalo, the consumption of milk from this animal may account for the presence of antibodies in the $23 \%$ of non-Caucasians found to be positive by ELISA IgG. Studies have shown that the prevalence of antibodies to $T$ gondii in buffalo sera in India range from 10 to $24 \%$ (32-34).

In the present study a titre of 1:100, the first dilution recorded, was generally regarded as a borderline result or the cut-off point. In general, titres of 1:800 to 1:1600 or greater together with a positive IgM reaction are considered to be indicative of recent acute infection. However, studies have shown that the presence of IgM-specific antibody may not be the ideal indicator of recent infection, since the persistence of these antibodies varies greatly from individual to individual (35).

Two of the three participants with positive IgM reactions of 1:100 were Caucasians. Both participants had at some stage owned a cat, were nonvegetarians and had on occasion consumed unpasteurized milk. The third participant with a similar titre was a nonvegetarian Hindu male who did not own a cat but had regularly consumed unpasteurized milk. The participant with the IgM titre of 1:400 was a Caucasian male, who owned a cat but did not drink unpasteurized milk. He was a meat cutter by profession, and several weeks previously in the course of his work had cut his hand. Histological findings of a lymph node biopsy, taken at about the same time as the serum sample for this study, were considered to be consistent with toxoplasmosis, suggesting that the infection had been acquired from meat he was handling at the time or from the meat block. In this instance, the high IgG titre and the positive IgM were considered to be diagnostic of acute toxoplasmosis. The low IgM titre of the other three participants is suggestive of an infection acquired at some earlier date.

In conclusion, the seroprevalence of the population studied was found to be $20.7 \%$, a finding that is considerably lower than the $40 \%$ recorded for British Columbia in 1976 (36) or the $28 \%$ determined by methylene blue dye test in inhabitants of the Greater Victoria area in 1977 (37). The previous finding of 40\% was based on serum samples from all age groups from across the province submitted over a period of 16 years for routine testing for toxoplasmosis, and very likely reflects seasonal variations and the anticipated higher incidence associated with individuals from rural parts of the province. On the other hand, the present finding is in 
all probability a relatively accurate estimate of the overall seroprevalence of toxoplasmosis in the mainly urban and suburban area of the lower Fraser Valley of British Columbia. While the cat is known to be central to the dissemination and acquisition of toxoplasmosis, based on the present epidemiological findings, it appears that indirect transmission by way of oocysts in the environment and hence via cysts in food source animals is a more likely method of acquiring toxoplas-

\section{REFERENCES}

1. Nicole C, Manceaux I. Sur une infection a corps de Leishman (ou organisms voisins) due gondi. Compt Acad Sc 1908; 147:763-6.

2. Canning EU. Protozoan infections. Trans R Soc Trop Med Hyg 1990;84:19-24.

3. Reimann HP, Meyer ME, Theis JH, Kelso G, Behymer DE. Toxoplasmosis in an infant fed unpasteurized goat milk. J Pediatr 1975;87:573-6.

4. Sacks JJ, Roberto R, Brooks NF. Toxoplasmosis infection associated with raw goats' milk. JAMA 1982;248:1728-32.

5. Ffrench GE, Fish NA. A survey of toxoplasmosis in an Ontario community. Can Med Assoc J 1961;84:757-67.

6. Viens P, Morisset R, Stefanescu I, Strykowski H. La toxoplasmose en milieu Québécois. I-Résultats d'une enquête séro-épidémiologique par la technique d'immunofluorescence. Union Mèd Canada 1973:102:2072-7.

7. Tanner CE, Staudt M, Adamowski R, Lussier M. Bertrans S, Pritchard RK. Seroepidemiological study for five different zoonotic parasites in northern Quebec. Can $J$ Public Health 1987:78:262-6.

8. Dubey JP, Beattie CP. Toxoplasmosis of Animals and Man. Boca Raton: CRC Press, 1988.

9. Frenkel JK. Toxoplasmosis in human beings. J Am Vet Med Assoc 1990;196:240-8.

10. Tizard IR, Chauhan SS, Lai CH. The prevalence and epidemiology of toxoplasmosis in Ontario. J Hyg Camb 1977:78:275-82.

11. van den Veen J, Polak MF. Prevalence of Toxoplasma antibodies according to age with comments on the risk of prenatal infection. J Hyg Camb 1980;85:165-74.

12. Wallace CD. The prevalence of toxoplasmosis on Pacific islands and the influence of ethnic groups. Am J Trop Med Hyg 1976;25:48-53.

13. Desmonts G. Diagnostic serologique de la Toxoplasmose. Pathol Biol (Paris) 1960;8:109-25.

14. Remington J, Desmonts G. Infectious Diseases of Fetus and Newborn. Infant Serologic Tests. Philadelphia: WB Saunders Co, 1976:191-231.

15. Dubey JP. Toxoplasmosis. J Am Vet Med Assoc 1986:189:166-70.

16. Remington JS. Toxoplasmosis and congenital infection. Birth Defects 1968;4:49-56.

17. Jacobs L, Remington JS, Melton ML. A survey of meat samples from swine, cattle and sheep for the presence of encysted Toxoplasma. J Parasitol 1960;46:23-8.

18. Dubey JP, Murrel KD, Fayer R. Persistence of encysted Toxoplasma gondii in tissues of pigs fed oocysts. Am J Vet Res 1984;45:1941-3.

19. Dubey JP, Murrell KD, Fayer R, et al. Distribution of mosis than by direct contact with cats. The possible role of unpasteurized milk, and particularly buffalo milk, in the acquisition of toxoplasmosis is an interesting one and should be further investigated. The present study has also shown that over $80 \%$ of females of all ethnic origins in the childbearing age group are seronegative and therefore at risk of acquiring toxoplasmosis during pregnancy and of transmitting the infection transplacentally.

Toxoplasma gondii tissue cysts in commercial cuts of pork. J Am Vet Med Assoc 1986;188:1035-7.

20. Ruiz A, Frenkel JK. Intermediate and transport hosts of Toxoplasma gondii in Costa Rica. Am J Trop Med Hyg 1980:29:1161-6.

21. Peterson DR, Tronca E, Bonin P. Human toxoplasmosis prevalence and exposure to cats. Am J Epidemiol 1972:96:215-8.

22. Swartzberg JD, Remington JS. Transmission of toxoplasma. Am J Dis Child 1975; 129:777-9.

23. Teutsch SM, Juranek DD, Sulzer A, et al. Epidemic toxoplasmosis associated with infected cats. N Engl J Med 1978;300:695-9.

24. Shenep JL, Barenkamp SJ, Brammeier SA, et al. An outbreak of toxoplasmosis on an Illinois farm. Pediatr Infect Dis 1984:3:518-22.

25. Stagno S, Dykes AC, Amos CS, et al. An outbreak of toxoplasmosis linked to cats. Pediatrics 1980;65:706-12.

26. Benenson MW, Takafuji ET, Lemon SM, et al. Oocyst transmitted toxoplasmosis associated with ingestion of contaminated water. N Engl J Med 1982;307:666-9.

27. Munday BL, Mason RW. Toxoplasmosis as a cause of perinatal death in goats. Aust Vet J 1979:55:485-7.

28. Nurse GH, Lenghaus C. An outbreak of Toxoplasma gondii abortion, mummification and perinatal death in goats. Aust Vet J 1986:63:27-30.

29. McSporran KD, McCaughan C, Curral JHS, et al. Toxoplasmosis in goats. $\mathrm{N} Z$ Vet $\mathrm{J}$ 1985:33:39-40.

30. Chhabra MB, Bhardwaj RM, Gautam OP, et al. Toxoplasma infection and abortion in dairy goats. Trop Anim Health Prod 1981;13:222-6.

31. Dubey JP. Epizootic toxoplasmosis associated with abortion in dairy goats in Montana. J Am Vet Med Assoc 1981;178:661-70.

32. Gill HS. Toxoplasma in India: a note on the prevalence of dye-test antibodies in Indian water-buffalo. Indian $\mathrm{J}$ Anim Sci 1972;42:1027-40.

33. Chhabra MB, Mahajan RC. A serological study on toxoplasmosis prevalence on buffaloes in North India. Riv Parasitol 1978;39:39-43.

34. Chhabra MB, Gupta SL, Gautam OP. Toxoplasma seroprevalence in animals in northern India. Int $\mathrm{J}$ Zoon 1985; 12:136-42.

35. Fuccillo DA, Madden DL, Tzan N, et al. Difficulties associated with serological diagnosis of Toxoplasma gondii infections. Diagn Clin Immunol 1987;5:8-13.

36. Tizard IR, Fish NA, Quinn JP. Some observations on the epidemiology of toxoplasmosis in Canada. J Hyg Camb 1976;77:11-21.

37. Karim KA, Trust TJ. Toxoplasmosis in Greater Victoria. Can Med Assoc J 1977; 1 17:895-9. 


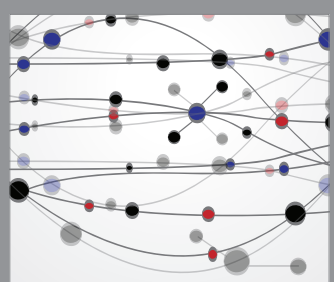

The Scientific World Journal
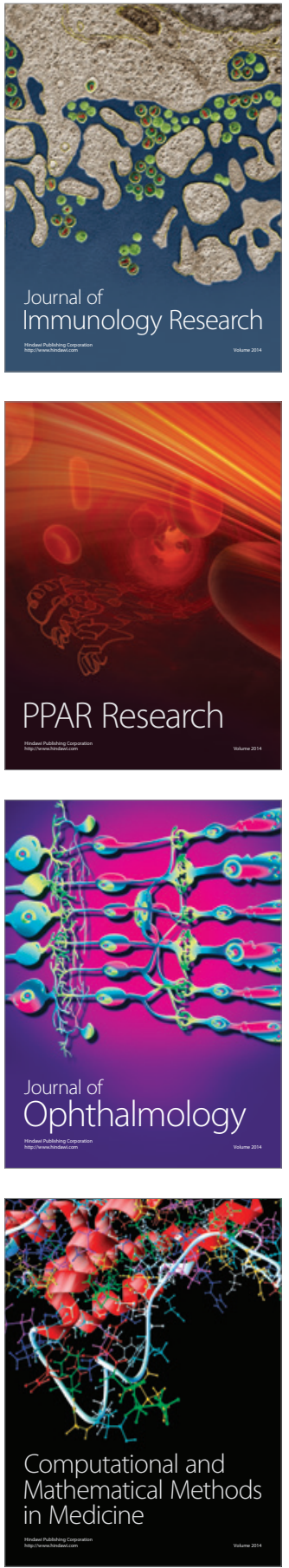

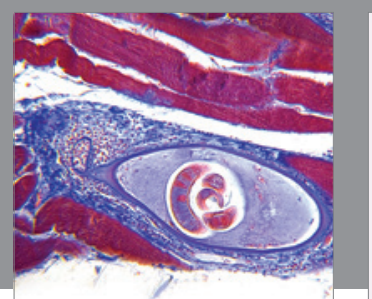

Gastroenterology Research and Practice

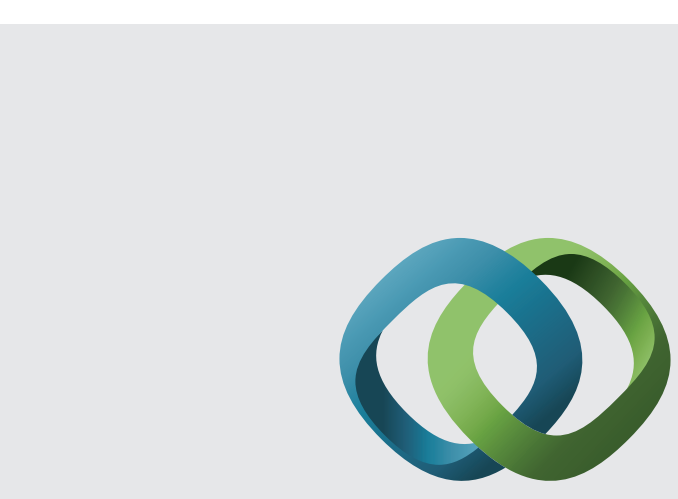

\section{Hindawi}

Submit your manuscripts at

http://www.hindawi.com
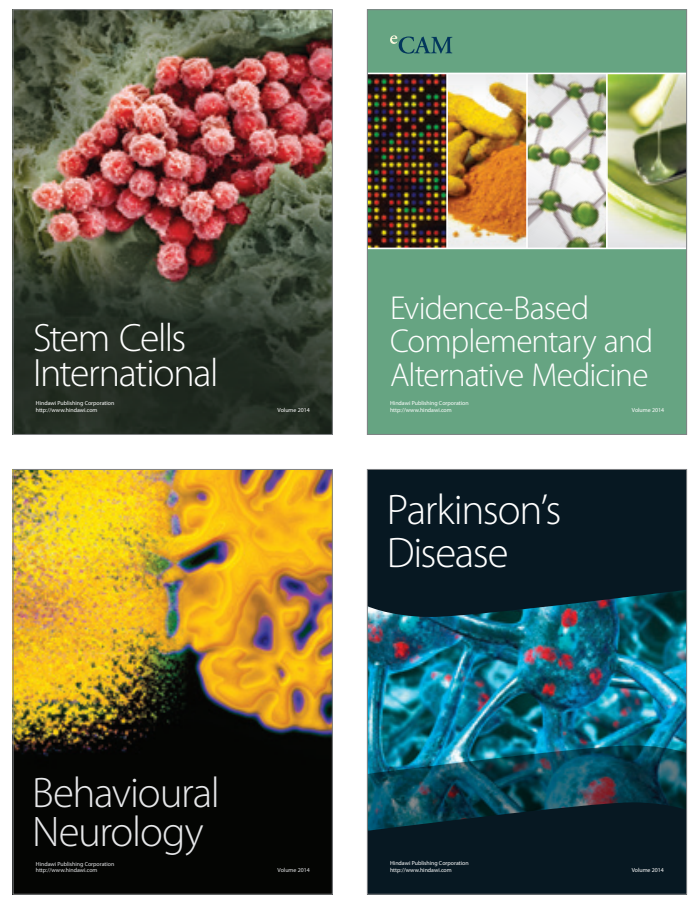
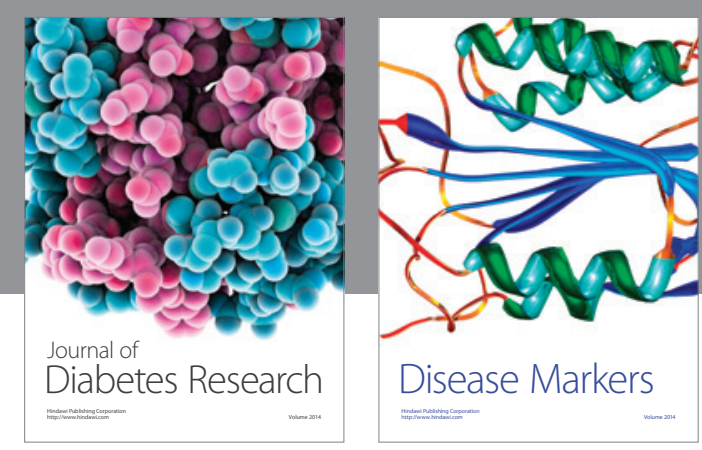

Disease Markers
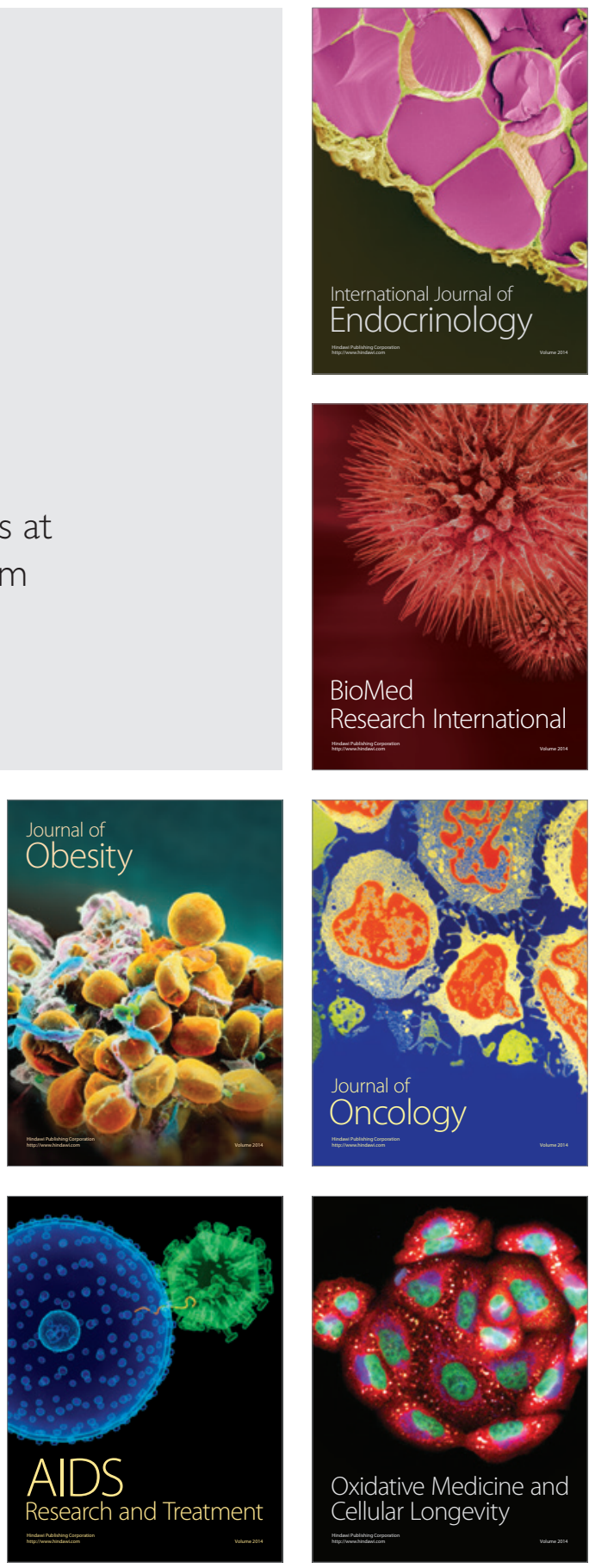